Article

\title{
Proanthocyanidins Protect against $\beta$-Hydroxybutyrate-Induced Oxidative Damage in Bovine Endometrial Cells
}

\author{
Xi Cheng ${ }^{1,+} \oplus$, Shuhua Yang ${ }^{1,+}$, Chuang $X^{2}{ }^{2}$, Lanzhi Li ${ }^{1}$, Yi Zhang ${ }^{1}$, Yang Guo ${ }^{1}$, Cai Zhang ${ }^{3}$, \\ Peng $\mathrm{Li}^{1, *}$, Miao Long ${ }^{1, * \mathbb{D}}$ and Jianbin $\mathrm{He}^{1, *}$
}

1 Key Laboratory of Zoonosis of Liaoning Province, College of Animal Science and Veterinary Medicine, Shenyang Agricultural University, Shenyang 110161, China; chengxi1129@163.com (X.C.); yangshuhua0001@126.com (S.Y.); 18304076080@163.com (L.L.); sihuo12345@sohu.com (Y.Z.); jessekuo@163.com (Y.G.)

2 Heilongjiang Provincial Key Laboratory of Prevention and Control of Bovine Diseases, Heilongjiang Bayi Agricultural University, Daqing 163319, China; xuchuang7175@163.com

3 College of animal science, Henan University of Science and Technology, Luoyang 471003, China; zhangcai@haust.edu.cn

* Correspondence: lipeng79625@163.com (P.L.); longjlau@126.com (M.L.); hejianbin69@163.com (J.H.); Tel./Fax: +86-24-8848-7156 (P.L. \& M.L. \& J.H.)

+ These authors contributed equally to this work.

Academic Editors: Luciano Saso, Neda Mimica-Dukić and Ryszard Amarowicz Received: 17 December 2018; Accepted: 18 January 2019; Published: 22 January 2019

\begin{abstract}
Metabolic diseases, such as ketosis, are closely associated with decreased reproductive performance (such as delayed estrus and decreased pregnancy rate) in dairy cows. The change of $\beta$-hydroxybutyrate (BHBA) concentration in dairy cattle is an important mechanism leading to ketosis, and its blood concentration in ketotic cows is always significantly higher than in nonketotic cows. Many studies indicated that BHBA can induce oxidative damage in liver and other organs. Proanthocyanidins $(P C s)$ have gained substantial attention in the last decade as strong antioxidative substances. This study aimed to demonstrate a protective effect of PCs against $B H B A$-induced oxidative stress damage in bovine endometrial (BEND) cells by activating the nuclear erythroid2-related factor2 (Nrf2) signaling pathway. Our research show that $P C s$ could significantly increase activities of catalase (CAT) and glutathione peroxidase (GSH-PX), glutathione (GSH) content, and antioxidant capacity (T-AOC), while significantly decreasing malondialdehyde (MDA) content in BEND cells. Both mRNA and protein expression levels of Nrf2 were significantly increased in BEND cells, and glutamate-cysteine ligase catalytic subunit (GCLC), heme oxygenase 1 (HO-1), manganese superoxide dismutase (Mn-SOD), and $N A D(P) H$ quinone dehydrogenase 1 (NQO-1) were also significantly increased. These results indicate that $P C$ s can antagonize $B H B A$-induced oxidative damage by activating the Nrf2 signaling pathway to exert an antioxidant effect.
\end{abstract}

Keywords: proanthocyanidin; $\beta$-hydroxybutyrate; oxidative stress; Nrf2 signaling pathway; bovine endometrial cells

\section{Introduction}

Ketosis occurring in dairy cows during transition period is associated with the negative energy balance (NEB). The main mechanism of NEB was the reduction of dry matter intake and the increase of energy expenditure in early postpartum period [1]. Previous studies have demonstrated that NEB triggers excessive fat mobilization and increases blood concentrations of nonessential fatty acids (NEFAs). NEFAs are first fully oxidized to provide the energy requirement for the liver 
and, subsequently, large quantities of NEFAs are converted to ketones (mainly BHBA) [2]. BHBA concentration in blood is always used for diagnosis of ketosis [3]. In addition, many studies have shown that $B H B A$ is associated with energy metabolism, neuroprotection, and ATP production [4], and it can cause oxidative stress, inflammatory response, and even cellular apoptosis, by activating signaling pathways [5,6]. BHBA can efficiently activate the Nrf2 pathway in classical Keap1-Cys151, and induce pathway activation in a dependent manner [7].

The structure and function of cow uterus is important for pregnancy in the next estrous cycle. Recent studies have shown that oxidative stress can affect subsequent physiological changes and metabolic functions by excessive oxidation of lipids and damage of cells in dairy cows [8]. It has been proposed that $B H B A$ may play a key role in oxidative stress in dairy cows [9]. Oxidative stress is linked to uterine diseases. In humans, oxidative stress-related changes in uterine fibroid tissue samples result in infertility-related conditions, suggesting that oxidative stress plays an important role in female reproduction [10-12]. In rats, Marzenna showed that oxidative stress and lipid peroxidation induced by toxic $\mathrm{Cd}$ may affect uterus function [13]. When the balance of reactive oxygen species (ROS) and antioxidants failed, it directly affected the state of embryo and uterus in cows, resulting in loss of embryo [14]. Moreover, numerous publications reported the association of ketosis and fertility traits in dairy cows. One study found that circulating $B H B A$ was increased the conception rate at first service and fetal loss was decreased in cows [15], and the calving-to-first-service interval and the calving-to-conception interval were prolonged with subclinical ketosis [16]. It was also found that a combination of NEB and reduced dry matter intake reduced fertility and milk production in dairy cows [17].

Proanthocyanidins (PCs) exhibit potent antioxidant activity due to scavenging of free radicals, and are widely present in nature [18]. PCs commonly exist in daily diets, and they are easy to extract, soluble in water, and suitable for in vitro assays [19]. Many studies indicated PCs can improve oxidative stress and degenerative diseases, including modulation of lipid and glucose metabolism [20], enhancement of innate immunity [21], and protection from neurological disorders [22], acute and chronic stress [23], and carcinogenesis [24]. The current literature confirms that, as antioxidants, PCs are better than vitamin $\mathrm{E}\left(\mathrm{V}_{\mathrm{E}}\right)$ and have protective effects against apoptosis [25]. It was also found that feeding dairy cows grape seed and grape marc extract (GSGME) increases milk yield [26] and reduces methane emissions by affecting rumen metabolism [27], but does not influence inflammation or endoplasmic reticulum (ER) stress in the liver. In other studies, $P C s$ were associated with antioxidant activity and the ability to activate the Nrf2 defense pathway [28,29].

The purpose of our research was to reveal whether PCs could protect bovine endometrial (BEND) cells from oxidative stress by activating the Nrf2 pathway. This study elucidates a protective mechanism from oxidative stress in dairy cows in transition period.

\section{Results}

\subsection{The Effect of BHBA and PCs on the Relative Viability in BEND Cells}

At all time points, relative cell viability was decreased with increasing $B H B A$ concentration. However, the relative cell survival rate with $0.6 \mathrm{mmol} / \mathrm{L} B H B A$ was higher than in the control group. Only at $24 \mathrm{~h}$ of treatment did each $B H B A$ concentration cause a significant difference in cell viability $(p<0.01)$ compared to the control group. Compared with 6,12 , and $24 \mathrm{~h}$ treatment with $B H B A$, relative cell viability increased when treated for $48 \mathrm{~h}$ (Figure 1). 


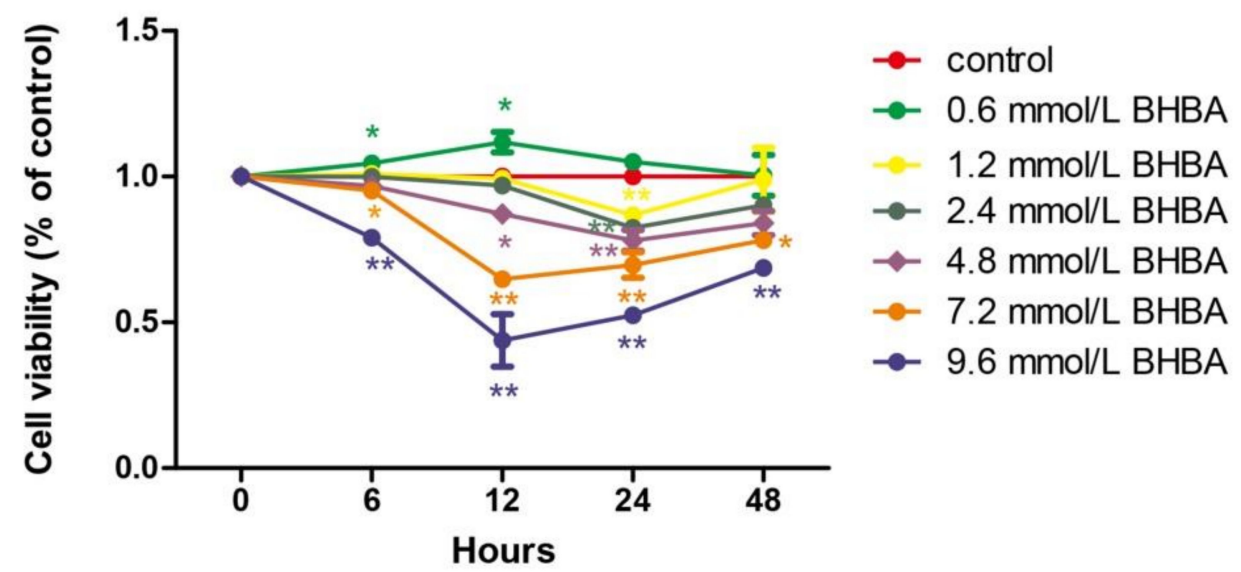

Figure 1. The effect of different of times and $\beta$-hydroxybutyrate $(B H B A)$ concentrations on the relative viability of bovine endometrial (BEND) cells. ${ }^{*} p<0.05$ vs. control group, ${ }^{* *} p<0.01$ vs. control group.

At all time points, relative cell viability after treatment with $10 \mu \mathrm{mol} / \mathrm{L}$ PCs was higher than in the control group. Compared to the control group, the effect of $10 \mu \mathrm{mol} / \mathrm{L}$ PCs added to cells for $24 \mathrm{~h}$ was significant $(p<0.05)$ (Figure 2).

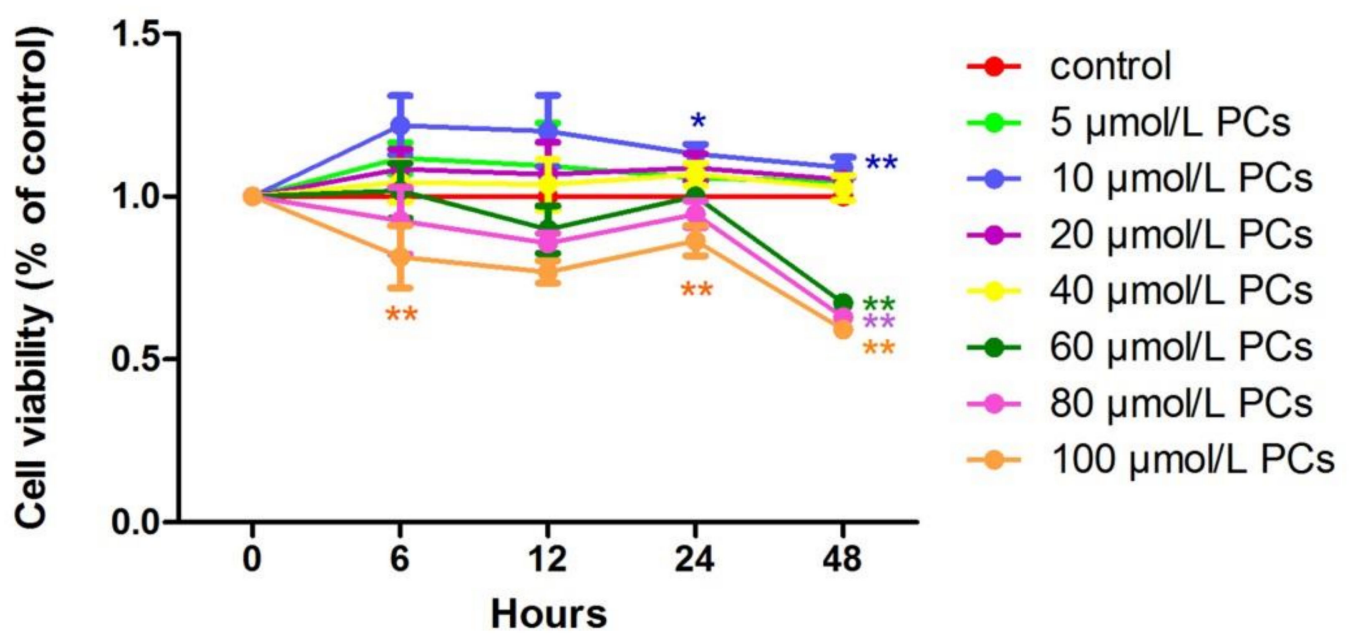

Figure 2. The effect of different of times and concentrations of proanthocyanidins (PCs) on the relative viability of BEND cells. ${ }^{*} p<0.05$ vs. control group, ${ }^{* *} p<0.01$ vs. control group.

Compared to the control group, the relative viability of cells treated with $B H B A$ at 1.2 and $2.4 \mathrm{mmol} / \mathrm{L}$ significantly decreased $(p<0.01)$, but not in the $B H B A 0.6 \mathrm{mmol} / \mathrm{L}$ group $(p>0.05)$, whereas in the $P C s$ group, viability significantly increased $(p<0.01)$. Compared with the BHBA-treated group, the relative cell viability in the $B H B A 1.2$ and $2.4 \mathrm{mmol} / \mathrm{L}+P C s$ groups were increased $(p>$ 0.01 , and in the $B H B A 0.6 \mathrm{mmol} / \mathrm{L}+P C s$ group, viability was almost constant. After the addition of $P C s$, the cell relative viability was significantly decreased $(p<0.05)$ converted from very significantly decreased $(p<0.01)$, compared with the control group (Figure 3$)$. 


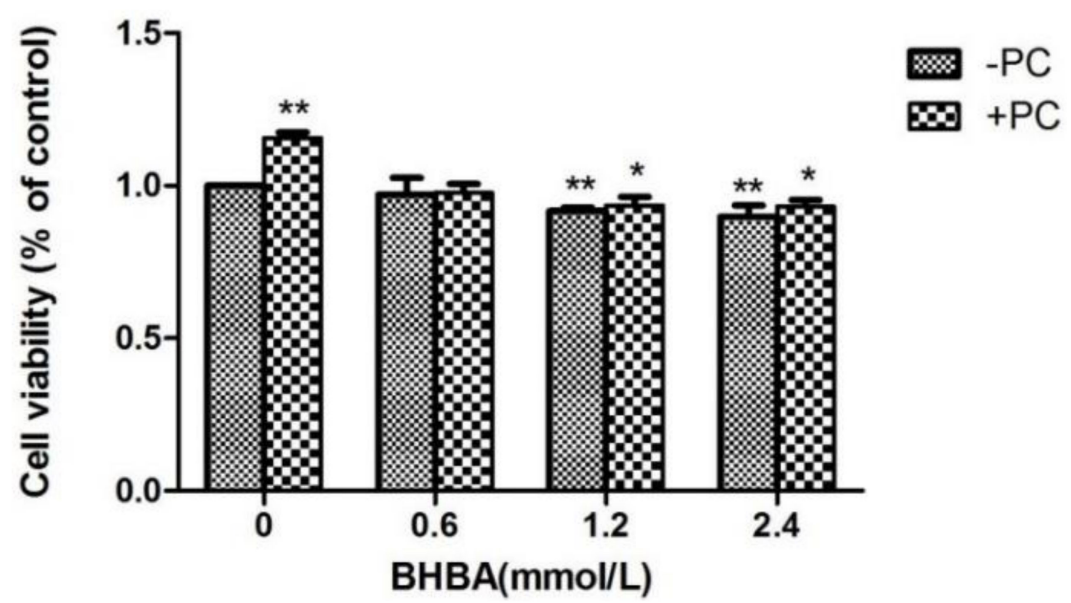

Figure 3. Effects of different $B H B A$ concentrations and fixed $P C s$ concentration of $10 \mu \mathrm{mol} / \mathrm{L}$ on relative viability of simultaneously treated BEND cells. ${ }^{*} p<0.05$ vs. control group, ${ }^{* *} p<0.01$ vs. control group.

Compared with the control group, the relative cell viability in all $B H B A$ groups significantly decreased $(p<0.01)$, and the relative cell viability in the $P C s$ group did not increased. Compared with the $B H B A$-treated group, the relative cell viability of $B H B A+P C s$ groups also showed no significant increase $(p>0.05)$ (Figure 4). Based on the above results, we chose BHBA concentrations of $0.6,1.2$ and $2.4 \mathrm{mmol} / \mathrm{L}$ and $P C s$ concentration of $10 \mu \mathrm{mol} / \mathrm{L}$ for PC pretreated to BEND cells.

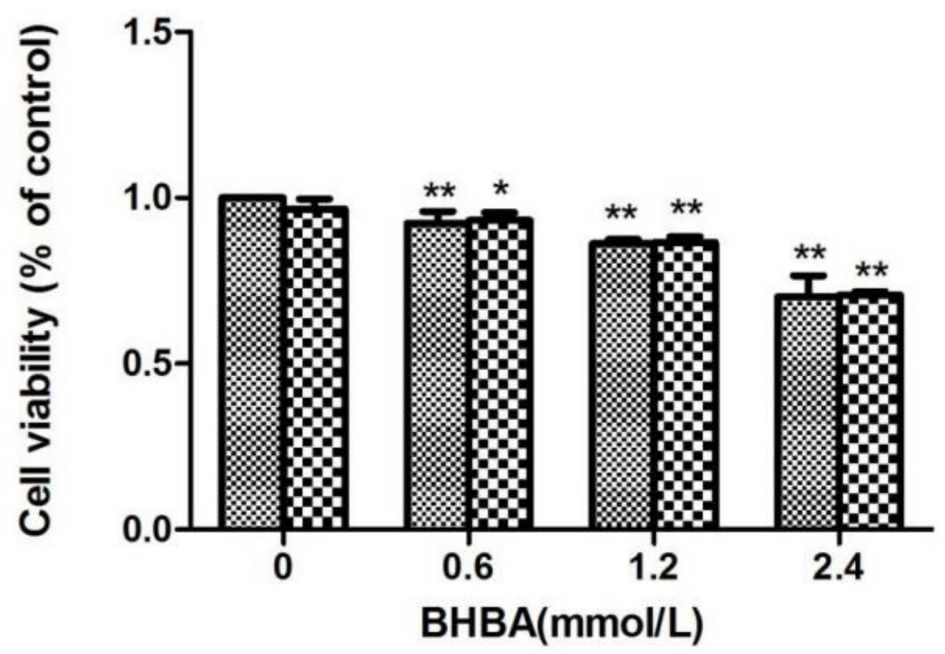

Figure 4. Effects of different $B H B A$ concentrations and $P C$ s pretreatment on the relative viability of BEND cells. ${ }^{*} p<0.05$ vs. control group, ${ }^{* *} p<0.01$ vs. control group.

\subsection{Effects of PCs and BHBA on SOD, CAT, GSH, GSH-PX, T-AOC, and MDA in BEND Cells}

Compared with the control group, $C A T$ activity and GSH content in $B H B A$-treated groups were significantly decreased $(p<0.05)$, and activities of GSH-PX and SOD in BHBA-treated groups were not affected significantly $(p>0.05)$, and the $T$ - $A O C$ content was decreased significantly in $2.4 \mathrm{mmol} / \mathrm{L}$ $B H B A$ group $(p<0.05)$. The content of $M D A$ was not significantly increased $(p>0.05)$ except in the $2.4 \mathrm{mmol} / \mathrm{L} B H B A$ group $(p<0.05)$. Compared with the BHBA-treated group, activities of $C A T$ and GSH-PX, and contents of GSH and T-AOC in cotreated groups were all significantly increased, $S O D$ activity in the cotreated group was not significantly increased except in the PCs group $(p<0.05)$, and the $M D A$ content in the cotreated group was not significantly decreased $(p>0.05)$, except in the $2.4 \mathrm{mmol} / \mathrm{L} B H B A$ group $(p<0.05)$ (Figure 5). 


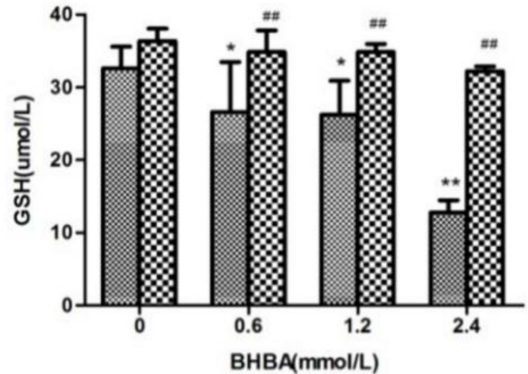

A
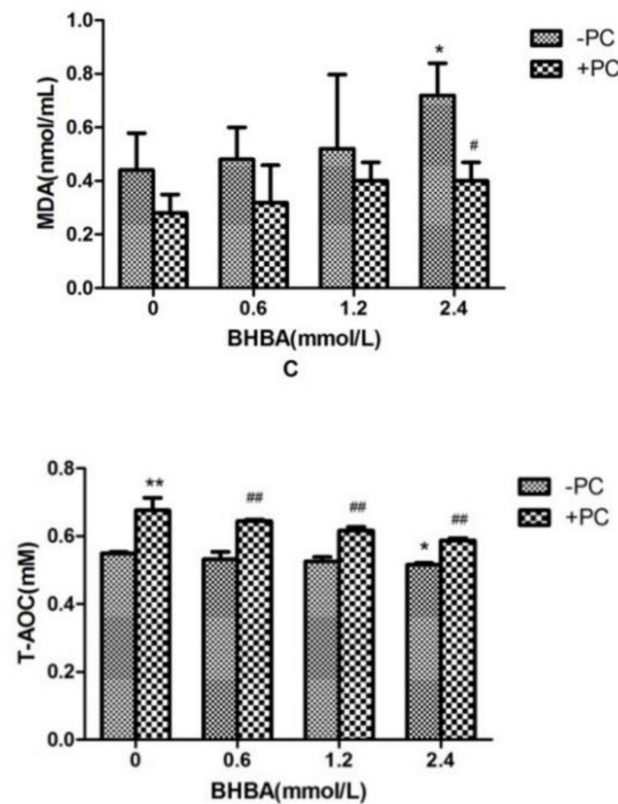

E
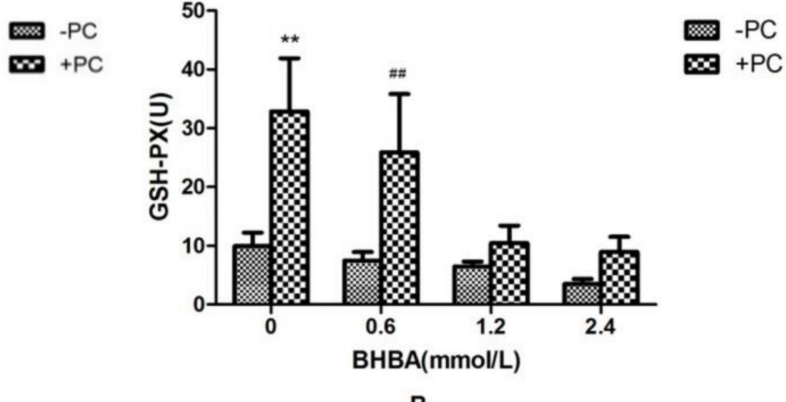

B
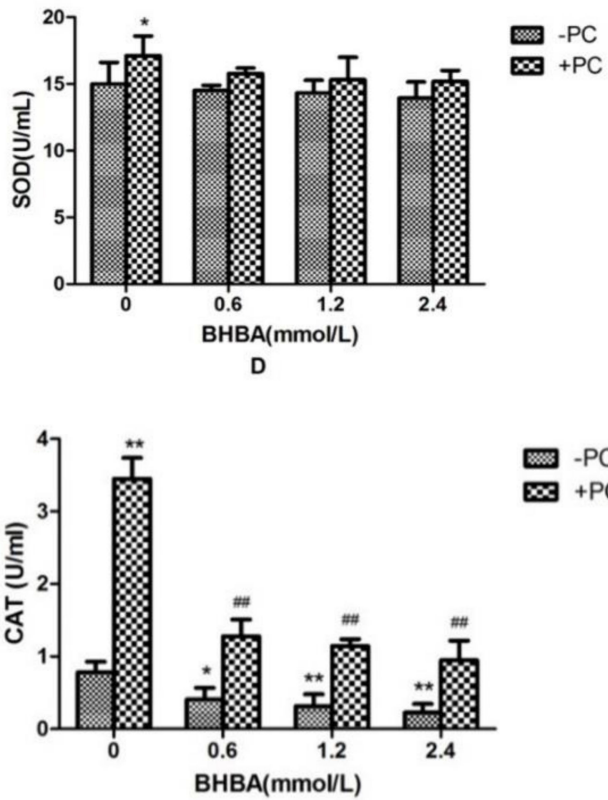

$\mathbf{F}$

Figure 5. Effects of $B H B A$ and $P C$ s on the antioxidation markers in BEND cells. (A) The GSH content. (B) The GSH-PX activity. (C) The MDA content. (D) The SOD activity. (E) The T-AOC. (F) The CAT activity. ${ }^{*} p<0.05$ vs. control group, ${ }^{* *} p<0.01$ vs. control group. $\# p<0.05$ vs. BHBA-treated group, $\# \#<0.01$ vs. BHBA-treated group.

\subsection{Effect of BHBA and PCs on the Related mRNA Expression of Nrf2 Signaling Pathway in BEND Cells}

We observed that the expression levels of GCLC in the 1.2 and $2.4 \mathrm{mmol} / \mathrm{L} B H B A$ groups was significantly increased $(p<0.01)$. By contrast, the expression levels of HO-1 in the $2.4 \mathrm{mmol} / \mathrm{L}$ $B H B A$-treated group was significantly decreased $(p<0.01)$. However, the expression of $M n-S O D$, $N Q O-1$, and Nrf2 were not changed significantly in all $B H B A$-treated groups. Meanwhile, expression of all genes in the $P C$ s group was significantly increased $(p<0.01)$. Compared with the BHBA-treated group, expression levels of GCLC, Mn-SOD, NQO-1, and Nrf2 in the cotreated groups were all significantly increased ( $p<0.01$ or $p<0.05$ ), except NQO-1 in the $2.4 \mathrm{mmol} / \mathrm{L} \mathrm{BHBA}$ cotreated group (Figure 6). When BEND cells were treated with $2.4 \mathrm{mmol} / \mathrm{L} \mathrm{BHBA}$ and PCs simultaneously, the expression of $H O-1$ was increased significantly compared with in the $2.4 \mathrm{mmol} / \mathrm{L} B H B A$ group. 

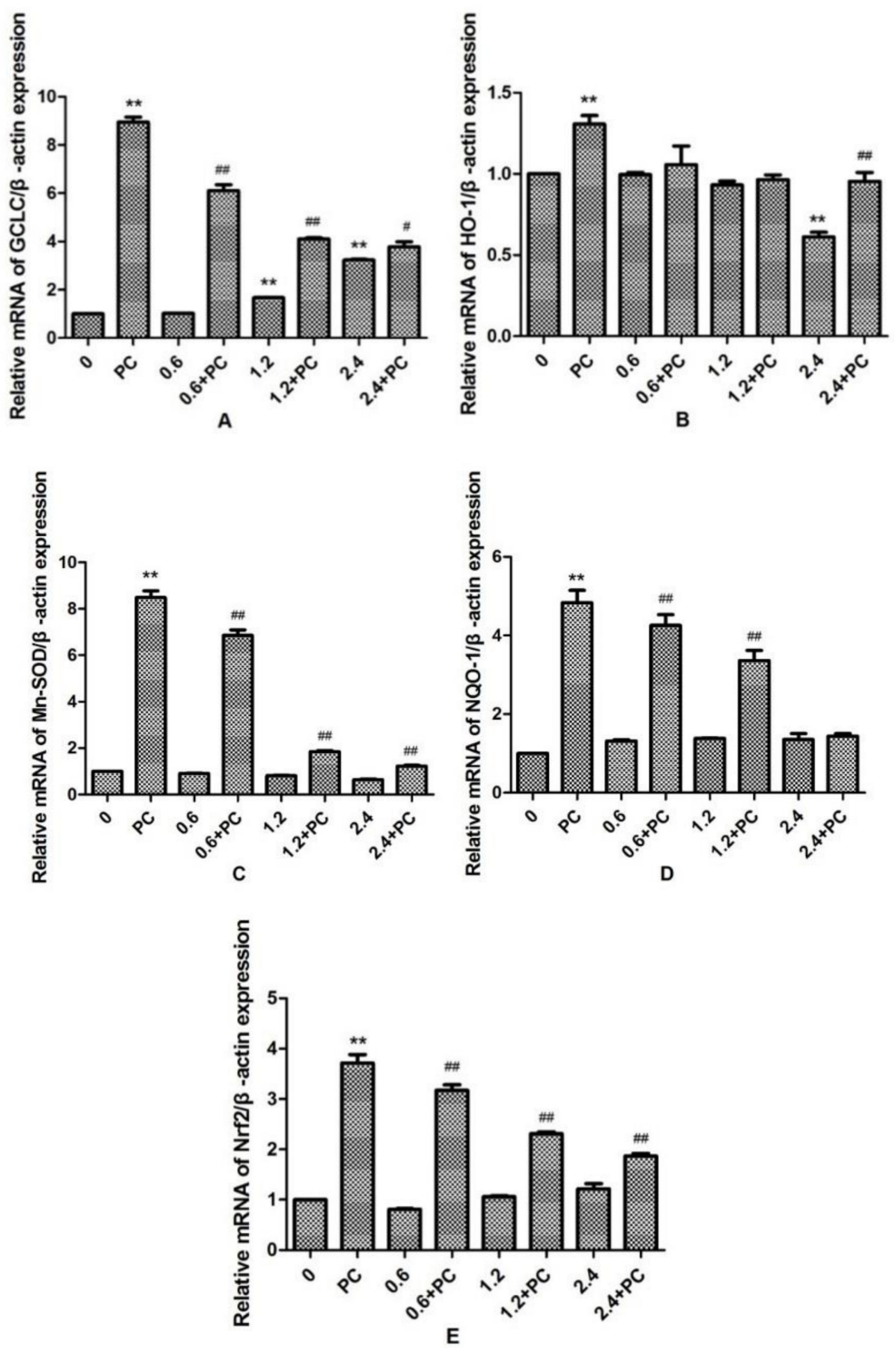

Figure 6. The effect of simultaneous treatment with BHBA and PCs on the mRNA expression of genes related to the Nrf2 signaling pathway in BEND cells. ${ }^{* *} p<0.01$ vs. control group. \# $p<0.05$ vs. $B H B A$-treated group, \#\# $p<0.01$ vs. BHBA-treated group.

\subsection{Effect of BHBA and PCs on Expression of Proteins Related to the Nrf2 Signaling Pathway in BEND Cells}

The protein expression levels of GCLC, HO-1, and Nrf2 in BHBA-treated groups were all significantly increased $(p<0.01)$, and NQO-1 was increased significantly in the $1.2 \mathrm{mmol} / \mathrm{L}$ and 2.4 $\mathrm{mmol} / \mathrm{L}$ groups, whereas protein expression of $M n$-SOD was not changed significantly. All proteins in the PCs-treated group had higher expression levels. Compared with the BHBA-treated group, all protein expression levels in the cotreated group were significantly increased $(p<0.01$ or $p<0.05)$, except GCLC in the $2.4 \mathrm{mmol} / \mathrm{L} \mathrm{BHBA}$ cotreated group (Figure 7). 

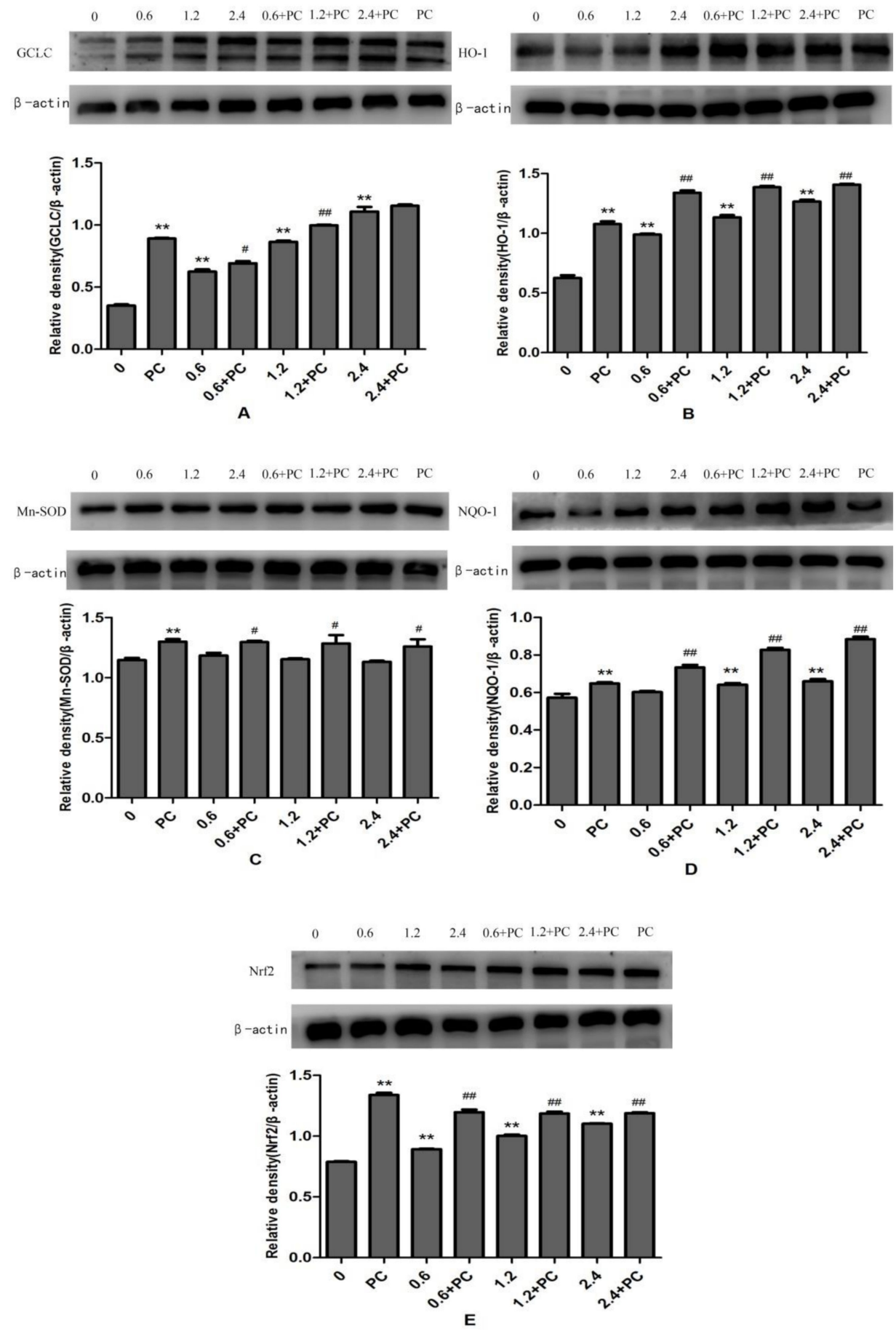

Figure 7. The effect of simultaneous treatment with $B H B A$ and $P C s$ on the protein expression of GCLC, HO-1, Mn-SOD, NQO-1, and Nrf2 in BEND cells. ${ }^{* *} p<0.01$ vs. control group. \# $p<0.05$ vs. $B H B A$-treated group, \#\# $p<0.01$ vs. BHBA-treated group.

\section{Discussion}

Dairy cows undergo tremendous physiological challenges to the homeostatic mechanisms in the transition period leading to transition stress in the form of increased oxidative stress, reduced immunological capacity, and generation of a negative energy balance (NEB), which ultimately results in impaired postpartum fertility [30]. Ketosis in cows is usually accompanied by severe oxidative stress and inflammatory response, which were mainly associated with increased $B H B A$ and NEFA concentration in blood [31]. Studies have shown high concentration of $B H B A$ can induce oxidative 
stress in abomasum smooth muscle cells and calf hepatocytes, and affect the function of abomasum and liver in cows [32,33], and Amine's research indicated high BHBA might pose a risk for metritis and placental retention and lead to reproductive disorders, but the association between uterus function and high $B H B A$ and its mechanism was unclear.

Oxidative stress-produced $R O S$ are eliminated by established antioxidant enzymes and numerous nonenzymatic defense mechanisms. In fact, the antioxidant enzymes, including $S O D, G S H-P X$, and $C A T$, are often measured as markers of the body's antioxidant capacity. Additionally, numerous nonenzymatic substances protect the body from oxidative stress, e.g., GSH [34,35]. MDA acts as a marker of lipid peroxidation in the body to reflect cellular damage [36]. The levels of $T$ - $A O C$ and $M D A$ directly reflect the body's oxidation and antioxidant capacity. Our results showed that GSH and CAT were decreased significantly when cells were treated with 1.2 and $2.4 \mathrm{mmol} / \mathrm{L} \mathrm{BHBA}$ whereas, in cells treated with $2.4 \mathrm{mmol} / \mathrm{L} B H B A, M D A$ was increased and $T$ - $A O C$ was decreased, significantly. The concentration of $B H B A$ was always more than $1.2 \mathrm{mmol} / \mathrm{L}$ in subclinical ketotic cows' blood, and might be more than $2.4 \mathrm{mmol} / \mathrm{L}$ in clinical ketotic cows' blood. The oxidation index of the BHBA $2.4 \mathrm{mmol} / \mathrm{L}$ treatment group all showed significant changes in addition to GSH-PX and $S O D$, which indicate clinical ketotic and subclinical ketotic dairy cows were experienced varying degrees of oxidative stress, and severe oxidative stress may lead to secondary diseases in dairy cows. However, after treatment with PCs and BHBA simultaneously, the levels of the above oxidation markers changed in the opposite direction. In short, these results demonstrated that $P C$ s can effectively relieve significant $B H B A$-induced oxidative stress in BEND cells, in agreement with previous studies of the antioxidant effect of $P C$ s during apoptosis in kidney tissue [23]. The free radical scavenging ability of $P C s$, directed at biochemically produced ROS and hydroxyl radicals, has been previously reported in vitro and in vivo. For example, a treatment with PCs could significantly decrease 3-nitropropionic acid (3-NPA)-induced oxidative damage in mouse ovaries [37]. Another study showed that PCs could act against $\mathrm{H}_{2} \mathrm{O}_{2}$-induced oxidative stress damage to protect key fibroblast (HDF) function by suppressing mitochondrial membrane damage in human diploid HDFs [38]. As previous studies have shown that cows with subclinical ketosis always have BHBA $>1.2 \mathrm{mmol} / \mathrm{L}$ in their blood, compared with nonketotic cows, our results confirmed that ketotic cows always experience an oxidative stress in endometrium, which affects the function of the uterus [2].

The Nrf2-ARE system can exert strong antioxidative stress in cells and is an important defense mechanism of the body. Nrf2 is a nuclear transcription factor that protects cellular homeostasis. The mechanism involves binding to antioxidant response elements (AREs) to activate a series of downstream antioxidant genes and proteins' expression, such as GCLC, HO-1, NQO-1, and Mn-SOD, in response to oxidative stress [39]. Numerous publications have shown that activation of the Nrf2 signaling pathway may help many kinds of cells to resist oxidative stress caused by ROS. Orientin (Ori), the antioxidative matter isolated from plants, may exhibit a protective role against $\mathrm{H}_{2} \mathrm{O}_{2}$-stimulated oxidative damage in RAW 264.7 cells by the increasing of HO-1 expression through the activation of the Nrf2 signaling pathway [40]. Previous studies also confirmed that nuclear factor erythroid-derived 2 (NFE2L2), formerly known as Nrf2, acts in the ARE pathway to protect bovine mammary epithelial cells (BMEC) against $\mathrm{H}_{2} \mathrm{O}_{2}$-induced oxidative stress injury [41]. To further demonstrate that oxidative stress may affect BEND cells through activation of the Nrf2 signaling pathway, we examined the mRNA and protein expression of Nrf2, HO-1, NQO-1, GCLC, and Mn-SOD. Our studies showed that when BHBA was applied to BEND cells alone, the mRNA expression of Nrf2-related genes were not changed significantly, except GCLC and HO-1, but the protein expression levels of GCLC, NQO-1, HO-1, and Nrf2 (but not $M n$-SOD) were higher, whereas for cells treated with PCs and BHBA simultaneously, all trends were enhanced compared to the $B H B A$ group, consistent with previous studies $[42,43]$. It was important that the GCLC gene encoded a catalytic subunit of the GCLC protein and was involved in the synthesis of GSH [44]. The HO-1 gene encoded the HO-1 enzyme to protect the body from oxidative stress by regulating the elimination of toxic hemoglobin and the formation of iron ions [45]. From the experimental results, we found that the mRNA expression of most Nrf2-related 
genes in the BHBA treatment group were not changed significantly, such as $M n-S O D$ and NQO-1, and it might be that the transcriptional regulation process was also affected by many factors, such as protein translation efficiency, stability, and miRNA interference, which is a scenario worthy of further exploration [46]. What we are interested in is that the mRNA and protein expression of $M n-S O D$ was not significantly changed in all $B H B A$ groups, but increased significantly in groups treated with $P C$ s and BHBA simultaneously, and more studies are needed to confirm the function of $M n-S O D$ in oxidative stress. These findings clearly demonstrate that PCs can ameliorate oxidative stress in BEND cells, potentially due to antioxidative activity and the ability to activate the Nrf2 pathway.

\section{Materials and Methods}

\subsection{Cell Culture}

Bovine endometrial cells (BEND cells) were purchased from BeNa Culture Collection (BNCC340413, Beijing, China). Cells were cultured in DME/F-12 medium (HyClone, Logan, UT, USA), supplemented with 10\% fetal bovine serum (BioInd, Beit-Haemek, Israel) and $\%$ penicillin/streptomycin (HyClone, Logan, UT, USA), at $37^{\circ} \mathrm{C}$ in an incubator with $95 \%$ air and $5 \% \mathrm{CO}_{2}$ atmosphere. The culture solution was changed each day, and subculture was conducted by trypsinization with $0.05 \%$ trypsin until the cells reached $85-90 \%$ confluence. The BEND cells were cultured in cell flasks and prepared for the following experiments.

\subsection{PCs, BHBA Preparation and Treatment}

In cows suffering from ketosis, serum $B H B A$ content is used as a reference [32]. PCs and $B H B A$ were obtained from Solarbio (Solarbio, Beijing, China). Preparation of $B H B A$ was as follows: $B H B A$ powder was fully dissolved in distilled water. This solution was filter-sterilized and stored at $-20^{\circ} \mathrm{C}$. Preparation of PCs was as follows: $B H B A$ powder was fully dissolved in distilled water. After filter-sterilization, this solution was stored at $4{ }^{\circ} \mathrm{C}$. When cells reached $85-90 \%$ confluence, BEND cells were treated with serum-free media prior to incubation with $B H B A$ or PCs.

\subsection{Cell Proliferation Assay}

Cell proliferation assays were performed with Cell Counting Kit-8 (CCK-8, Solarbio, Beijing, China) according to the manufacturer's instructions. Briefly, the cells $\left(2 \times 10^{6}\right.$ cells $\left./ \mathrm{mL}\right)$ were cultured in 96-well plates at $37^{\circ} \mathrm{C}$ in a $5 \% \mathrm{CO}_{2}$ incubator for 7-12 $\mathrm{h}$, then, the cells were treated with different concentrations of BHBA $(0-9.6 \mathrm{mM})$ and PCs $(0-100 \mu \mathrm{M})$ individually for $6,12,24$, or $48 \mathrm{~h}$. After replacing with fresh serum-free medium and adding $C C K-8$ reagent to 96-well plates, the cells were further incubated for an additional $1-3 \mathrm{~h}$ in the $37^{\circ} \mathrm{C}$ incubator. The absorbance at $450 \mathrm{~nm}$ was measured by a microplate reader, and the cell proliferation rate was calculated according to the formula. After obtaining the optimum concentration and time, we also performed a joint treatment, including a simultaneous treatment and pretreatment, as described above.

\subsection{Assessment of Oxidative Stress}

BEND cells $\left(2 \times 10^{6}\right.$ cells $\left./ \mathrm{mL}\right)$ were seeded in 6-well plates. Confluent $(90 \%)$ cells were stimulated with various concentrations of $B H B A$ and $P C s$ for $24 \mathrm{~h}$. The supernatant was used to determine the total antioxidant capacity $(T-A O C)$ and contents of superoxide dismutase $(S O D)$, malondialdehyde $(M D A)$, reduced glutathione $(G S H)$, glutathione peroxidase $(G S H-P X)$, and catalase $(C A T)$ kits (Jiancheng, Nanjing, China) according to the manufacturer's instructions.

\subsection{RNA Extraction and RT-PCR}

The total RNA from the treated cells was isolated by using TRIzol (RNAiso Plus, TaKaRa, Dalian, China) according to the manufacturer's instructions. RNA concentration and purity $(260 / 280)$ were determined using Ultra Low-Volume Spectrometer (BioDrop, Cambridge, UK). Approximately $5 \mu \mathrm{g}$ of 
each sample of total RNA was reverse-transcribed to cDNA with PrimeScript RT reagent kit (TaKaRa, Tokyo, Japan), as described in the manufacturer's protocol. cDNA was stored at $-20{ }^{\circ} \mathrm{C}$ until it was used for real-time PCR. The primers for RT-PCR were designed by Primer 5 software (IBM, Almon, NY, USA), and are listed in Table 1.

Table 1. Parameters for chemical structures.

\begin{tabular}{|c|c|c|c|}
\hline Gene & $\begin{array}{c}\text { GenBank } \\
\text { Accession NO. }\end{array}$ & Primer Sequence $\left(5^{\prime}-3^{\prime}\right)$ & Fragment Size \\
\hline$N r f 2$ & AC_000159.1 & $\begin{array}{l}\text { Forward: AGCGGCTTGAATGTTTGTCTT } \\
\text { Reverse: CCCAGTCCAACCTTTGTCGTC }\end{array}$ & $130 \mathrm{bp}$ \\
\hline$M n-S O D$ & AC_000166.1 & $\begin{array}{l}\text { Forward: AGTTGACTGCTGTATCTGTTGGTGTC } \\
\text { Reverse: GGTATGAACAAGCAGCAATCTGTAA }\end{array}$ & $239 \mathrm{bp}$ \\
\hline HO-1 & NM_001014912.1 & $\begin{array}{c}\text { Forward: AATATCGCCAGTGCCACCAAGTTC } \\
\text { Reverse: GTTGAGCAGGAAGGCGGTCTTG }\end{array}$ & $142 \mathrm{bp}$ \\
\hline GCLC & NM_001083674.1 & $\begin{array}{l}\text { Forward: CACCACGAACACCACATACGC } \\
\text { Reverse: ACCTGGATGATGCCAACGAGT }\end{array}$ & $198 \mathrm{bp}$ \\
\hline NQO-1 & AC_000175.1 & $\begin{array}{l}\text { Forward: GCTACTTGGAGCAAAATACAG } \\
\text { Reverse: CTTGGAACCTCAACTGACATA }\end{array}$ & $204 \mathrm{bp}$ \\
\hline$\beta$-actin & AC_000182.1 & $\begin{array}{l}\text { Forward: GCCCTGAGGCTCTCTTCCA } \\
\text { Reverse: GCGGATGTCGACGTCACA }\end{array}$ & $101 \mathrm{bp}$ \\
\hline
\end{tabular}

mRNA expression levels were measured by using SYBR Premix Ex Taq II (TaKaRa, Dalian, China) on the QuantStudio 3 gene amplification instrument (ABI, Waltham, MA, USA) real-time PCR analysis.

The cycling conditions were as follows: $95^{\circ} \mathrm{C}$ for $30 \mathrm{~s}$, and then 40 cycles of $95^{\circ} \mathrm{C}$ for $5 \mathrm{~s}, 60{ }^{\circ} \mathrm{C}$ for $34 \mathrm{~s}$, and $60^{\circ} \mathrm{C}$ for $1 \mathrm{~min}$. All amplifications were repeated three times. To analyze the relative level of expression of each mRNA, the melting curves were used to analyze and assess the accuracy of the PCR and the $2^{-\Delta \Delta \mathrm{Ct}}$ values were used to quantify gene expression.

\subsection{Western Blotting}

Total proteins were obtained from the treated BEND cells with a protein extraction kit (Solarbio, Beijing, China). The protein concentration was detected by the BCA method (Solarbio, Beijing, China). The proteins $(50 \mu \mathrm{g})$ were heated in loading buffer at $95{ }^{\circ} \mathrm{C}$ for $5 \mathrm{~min}$. Each protein sample was subjected to SDS-PAGE using a gel preparation kit (Solarbio, Beijing, China) to separate proteins, then proteins were transferred to the PAGE membrane and blocked with $5 \%$ skim milk at $4{ }^{\circ} \mathrm{C}$ overnight. After rinsing with TBST on a shaker, membranes were hybridized for $90 \mathrm{~min}$ at room temperature with anti-Nrf2 (1:2000, Abcam, Cambridge, UK), anti-GCLC (3:1000, Abcam), anti-HO-1 (3:1000, Abcam), anti-NQO-1 (1:2000, Novus, Centennial, CO, USA), anti-Mn-SOD (1:5000, Abcam), and anti- $\beta$-actin (1:1000, Cell Signaling) antibodies, respectively. After rinsing for $1 \mathrm{~h}$, membranes were incubated with corresponding horseradish peroxidase-conjugated secondary antibodies for $90 \mathrm{~min}$ at room temperature. After rinsing again for $1 \mathrm{~h}$, proteins were visualized using Enhanced Chemiluminescence (ECL) system. Finally, an image-analysis system was used to analyze the density of these target proteins.

\subsection{Statistical Analysis}

All values are expressed as the means \pm SEM. The statistically significant differences were assessed by analysis of variance (ANOVA) followed by Tukey's multiple comparisons test using GraphPad Prism v. 5.0 for Mac (GraphPad Software, La Jolla, CA, USA). Statistical significance was defined as $p<0.05$ or $p<0.01$. 


\section{Conclusions}

In summary, our study confirmed that BHBA could cause oxidative stress in BEND cells and might be the key factor leading to reproductive disorders in ketonic cows, whereas PCs can relieve the oxidative damage by activating the Nrf2 signaling pathway.

Author Contributions: Conceptualization, P.L. and X.C.; methodology, S.Y. and Y.Z.; data curation, C.X. and Y.G.; writing-original draft preparation, X.C. and C.Z.; writing-review and editing, L.L. and S.Y.; supervision, M.L.; funding acquisition, J.H.

Funding: This research was funded by the National Natural Science Foundation of China (grants No. 31872538; No.31772809; No. 31640084; No.31402263; No.31872537), and the Key Research and Development Program of Shenyang (No. 17-165-3-00, No.18-004-3-45), Natural Science Foundation of Henan (NO. 182300410087) Heilongjiang Provincial Key Laboratory of Prevention and Control of Bovine Diseases (PCBD201704).

Conflicts of Interest: The authors declare no conflict of interest.

\section{References}

1. Xu, C.; Xu, Q.; Chen, Y.; Yang, W.; Xia, C.; Yu, H.; Zhu, K.; Shen, T.; Zhang, Z. The relationship between Fibroblast Growth Factor-21 and characteristic parameters related to energy balance in dairy cows. BMC Vet. Res. 2015, 11, 1-7. [CrossRef] [PubMed]

2. McArt, J.A.; Nydam, D.V.; Oetzel, G.R.; Overton, T.R.; Ospina, P.A. Elevated non-esterified fatty acids and beta-hydroxybutyrate and their association with transition dairy cow performance. Vet. J. 2013, 198, 560-570. [CrossRef] [PubMed]

3. Itle, A.J.; Huzzey, J.M.; Weary, D.M.; von Keyserlingk, M.A. Clinical ketosis and standing behavior in transition cows. J. Dairy Sci. 2015, 98, 128-134. [CrossRef] [PubMed]

4. Laeger, T.; Metges, C.C.; Kuhla, B. Role of beta-hydroxybutyric acid in the central regulation of energy balance. Appetite 2010, 54, 450-455. [CrossRef] [PubMed]

5. Fu, S.P.; Li, S.N.; Wang, J.F.; Li, Y.; Xie, S.S.; Xue, W.J.; Liu, H.M.; Huang, B.X.; Lv, Q.K.; Lei, L.C.; et al. BHBA suppresses LPS-induced inflammation in BV-2 cells by inhibiting NF-kappaB activation. Med. Inflamm. 2014, 2014, 983401. [CrossRef] [PubMed]

6. Deng, Q.; Liu, G.; Liu, L.; Zhang, Y.; Yin, L.; Shi, X.; Wang, J.; Yuan, X.; Sun, G.; Li, Y.; et al. BHBA influences bovine hepatic lipid metabolism via AMPK signaling pathway. J. Cell. Biochem. 2015, 116, 1070-1079. [CrossRef] [PubMed]

7. Shen, T.; Jiang, T.; Long, M.; Chen, J.; Ren, D.M.; Wong, P.K.; Chapman, E.; Zhou, B.; Zhang, D.D. A curcumin derivative that inhibits vinyl carbamate-induced lung carcinogenesis via activation of the Nrf2 protective response. Antioxid. Redox Signal. 2015, 23, 651-664. [CrossRef]

8. Bernabucci, U.; Ronchi, B.; Lacetera, N.; Nardone, A. Influence of body condition score on relationships between metabolic status and oxidative stress in periparturient dairy cows. J. Dairy Sci. 2005, 88, 2017-2026. [CrossRef]

9. Bicalho, M.L.; Marques, E.C.; Gilbert, R.O.; Bicalho, R.C. The association of plasma glucose, BHBA, and NEFA with postpartum uterine diseases, fertility, and milk production of Holstein dairy cows. Theriogenology 2017, 88, 270-282. [CrossRef]

10. Markowska, A.; Mardas, M.; Gajdzik, E.; Zagrodzki, P.; Markowska, J. Oxidative stress markers in uterine fibroids tissue in pre- and postmenopausal women. Clin. Exp. Obstet. Gynecol. 2015, 42, 725.

11. Santulli, P.; Borghese, B.; Lemarechal, H.; Leconte, M.; Millischer, A.E.; Batteux, F.; Chapron, C.; Borderie, D. Increased serum oxidative stress markers in women with uterine leiomyoma. PloS ONE 2013, 8, e72069. [CrossRef]

12. Gupta, S.; Ghulmiyyah, J.; Sharma, R.; Halabi, J.; Agarwal, A. Power of proteomics in linking oxidative stress and female infertility. BioMed Res. Int. 2014, 2014, 916212. [CrossRef] [PubMed]

13. Nasiadek, M.; Skrzypinska-Gawrysiak, M.; Darago, A.; Zwierzynska, E.; Kilanowicz, A. Involvement of oxidative stress in the mechanism of cadmium-induced toxicity on rat uterus. Environ. Toxicol. Pharmacol. 2014, 38, 364-373. [CrossRef] [PubMed]

14. Celi, P.; Merlo, M.; Barbato, O.; Gabai, G. Relationship between oxidative stress and the success of artificial insemination in dairy cows in a pasture-based system. Vet. J. 2012, 193, 498-502. [CrossRef] 
15. Mellado, M.; Dávila, A.; Gaytán, L.; Macías-Cruz, U.; Avendaño-Reyes, L.; García, E. Risk factors for clinical ketosis and association with milk production and reproduction variables in dairy cows in a hot environment. Trop. Anim. Health Prod. 2018, 50, 1-6. [CrossRef] [PubMed]

16. Raboisson, D.; Mounié, M.; Maigné, E. Diseases, reproductive performance, and changes in milk production associated with subclinical ketosis in dairy cows: A meta-analysis and review. J. Dairy Sci. 2014, 97, 7547-7563. [CrossRef] [PubMed]

17. Esposito, G.; Irons, P.C.; Webb, E.C.; Chapwanya, A. Interactions between negative energy balance, metabolic diseases, uterine health and immune response in transition dairy cows. Anim. Reprod. Sci. 2014, 144, 60-71. [CrossRef]

18. Chen, X.X.; Liang, G.; Chai, W.M.; Feng, H.L.; Zhou, H.T.; Shi, Y.; Chen, Q.X. Antioxidant and antityrosinase proanthocyanidins from Polyalthia longifolia leaves. J. Biosci. Bioeng. 2014, 118, 583-587. [CrossRef]

19. Blade, C.; Aragones, G.; Arola-Arnal, A.; Muguerza, B.; Bravo, F.I.; Salvado, M.J.; Arola, L.; Suarez, M. Proanthocyanidins in health and disease. BioFactors 2016, 42, 5-12.

20. Ribas-Latre, A.; Baselga-Escudero, L.; Casanova, E.; Arola-Arnal, A.; Salvado, M.J.; Blade, C.; Arola, L. Dietary proanthocyanidins modulate BMAL1 acetylation, Nampt expression and NAD levels in rat liver. Sci. Rep. 2015, 5, 10954. [CrossRef]

21. Dinh, J.; Angeloni, J.T.; Pederson, D.B.; Wang, X.; Cao, M.; Dong, Y. Cranberry extract standardized for proanthocyanidins promotes the immune response of Caenorhabditis elegans to Vibrio cholerae through the p38 MAPK pathway and HSF-1. PloS ONE 2014, 9, e103290. [CrossRef] [PubMed]

22. Puiggros, F.; Salvado, M.J.; Blade, C.; Arola, L. Differential modulation of apoptotic processes by proanthocyanidins as a dietary strategy for delaying chronic pathologies. Crit. Rev. Food Sci. Nutr. 2014, 54, 277-291. [CrossRef] [PubMed]

23. Sharma, S.D.; Meeran, S.M.; Katiyar, S.K. Dietary grape seed proanthocyanidins inhibit UVB-induced oxidative stress and activation of mitogen-activated protein kinases and nuclear factor-kappaB signaling in in vivo SKH-1 hairless mice. Mol. Cancer Ther. 2007, 6, 995-1005. [CrossRef]

24. Komsak, P.; Supachai, Y.; Pornngarm, L. Proanthocyanidin in red rice inhibits MDA-MB-231 breast cancer cell invasion via the expression control of invasive proteins. Biol. Pharm. Bull. 2015, 38, 571-581.

25. Bakar, E.; Ulucam, E.; Cerkezkayabekir, A. Protective effects of proanthocyanidin and vitamin E against toxic effects of formaldehyde in kidney tissue. Biotech. Histochem. Off. Publ. Biol. Stain Comm. 2015, 90, 69-78. [CrossRef]

26. Gessner, D.K.; Koch, C.; Romberg, F.J.; Winkler, A.; Dusel, G.; Herzog, E.; Most, E.; Eder, K. The effect of grape seed and grape marc meal extract on milk performance and the expression of genes of endoplasmic reticulum stress and inflammation in the liver of dairy cows in early lactation. J. Dairy Sci. 2015, 98, 8856-8868. [CrossRef]

27. Moate, P.J.; Williams, S.R.; Torok, V.A.; Hannah, M.C.; Ribaux, B.E.; Tavendale, M.H.; Eckard, R.J.; Jacobs, J.L.; Auldist, M.J.; Wales, W.J. Grape marc reduces methane emissions when fed to dairy cows. J. Dairy Sci. 2014, 97, 5073-5087. [CrossRef]

28. Chen, S.; Zhu, Y.; Liu, Z.; Gao, Z.; Li, B.; Zhang, D.; Zhang, Z.; Jiang, X.; Liu, Z.; Meng, L.; et al. Grape seed proanthocyanidin extract ameliorates diabetic bladder dysfunction via the activation of the Nrf2 pathway. PloS ONE 2015, 10, e0126457. [CrossRef]

29. Li, S.G.; Ding, Y.S.; Niu, Q.; Xu, S.Z.; Pang, L.J.; Ma, R.L.; Jing, M.X.; Feng, G.L.; Liu, J.M.; Guo, S.X. Grape seed proanthocyanidin extract alleviates arsenic-induced oxidative reproductive toxicity in male mice. Biomed. Environ. Sci. BES 2015, 28, 272-280. [PubMed]

30. Roche, J.R.; Burke, C.R.; Crookenden, M.A.; Heiser, A.; Loor, J.L.; Meier, S.; Mitchell, M.D.; Cvc, P.; Turner, S.A. Fertility and the transition dairy cow. Reprod. Fertil. Dev. 2018, 30, 85. [CrossRef]

31. Li, X.; Huang, W.; Gu, J.; Du, X.; Lei, L.; Yuan, X.; Sun, G.; Wang, Z.; Li, X.; Liu, G. SREBP-1c overactivates ROS-mediated hepatic NF-кB inflammatory pathway in dairy cows with fatty liver. Cell. Signal. 2015, 27, 2099-2109. [CrossRef] [PubMed]

32. Shi, X.; Li, X.; Li, D.; Li, Y.; Song, Y.; Deng, Q.; Wang, J.; Zhang, Y.; Ding, H.; Yin, L.; et al. Beta-hydroxybutyrate activates the NF-kappa B signaling pathway to promote the expression of pro-inflammatory factors in calf hepatocytes. Cell. Physiol. Biochem. 2014, 33, 920-932. [CrossRef] [PubMed] 
33. Wulin, T.; Teng, W.; Bin, L.; Zhe, W.; Naisheng, Z.; Guanghong, X. Pathway of programmed cell death and oxidative stress induced by $\beta$-hydroxybutyrate in dairy cow abomasum smooth muscle cells and in mouse gastric smooth muscle. PloS ONE 2014, 9, e96775.

34. Qiyi, C.; Wenkui, Y.; Jiangliang, S.; Juanhong, S.; Yimin, H.; Jianfeng, G.; Jieshou, L.; Ning, L. The effect of extracorporeal membrane oxygenation therapy on systemic oxidative stress injury in a porcine model. Artif. Org. 2014, 38, 426-431.

35. Liu, L.; Zhao, Y.F.; Han, W.H.; Chen, T.; Hou, G.X.; Tong, X.Z. Protective effect of antioxidant on renal damage caused by Doxorubicin chemotherapy in mice with hepatic cancer. Asian Pac. J. Trop. Med. 2016, 9 , 1078-1081. [CrossRef] [PubMed]

36. Tsikas, D.; Rothmann, S.; Schneider, J.Y.; Suchy, M.; Trettin, A.; Modun, D.; Stuke, N.; Maassen, N.; Frölich, J.C. Development, validation and biomedical applications of stable-isotope dilution GC-MS and GC-MS/MS techniques for circulating malondialdehyde (MDA) after pentafluorobenzyl bromide derivatization: MDA as a biomarker of oxidative stress and its relation to 15( S )-8- iso -prostaglandin F $2 \alpha$ and nitric oxide ( NO). J. Chromatogr. B 2016, 1019, 95-111.

37. Zhang, J.Q.; Xing, B.S.; Zhu, C.C.; Shen, M.; Yu, F.X.; Liu, H.L. Protective effect of proanthocyanidin against oxidative ovarian damage induced by 3-nitropropionic acid in mice. Genet. Mol. Res. Gmr 2015, 14, 2484-2494. [CrossRef]

38. Takako, Y.; Akiko, S.; Jung, K.Y. Modulation of oxidative stress by proanthocyanidin in H2O2-exposed human diploid fibroblast cells. Biosci. Biotechnol. Biochem. 2013, 77, 2056-2060.

39. Murakami, S.; Motohashi, H. Roles of NRF2 in cell proliferation and differentiation. Free Radic. Biol. Med. 2015, 88, 168-178. [CrossRef]

40. Xiao, Q.; Piao, R.; Wang, H.; Li, C.; Song, L. Orientin-mediated Nrf2/HO-1 signal alleviates H2O2 -induced oxidative damage via induction of JNK and PI3K/AKT activation. Int. J. Biol. Macromol. 2018, 118, 747-755. [CrossRef]

41. Ma, Y.F.; Wu, Z.H.; Gao, M.; Loor, J.J. Nuclear factor erythroid 2-related factor 2 antioxidant response element pathways protect bovine mammary epithelial cells against $\mathrm{H} 2 \mathrm{O} 2$-induced oxidative damage in vitro. J. Dairy Sci. 2018, 101, 5329-5344. [CrossRef] [PubMed]

42. Ma, Y.; Zheng, Y.X.; Dong, X.Y.; Zou, X.T. Effect of mercury chloride on oxidative stress and nuclear factor erythroid 2-related factor 2 signalling molecule in liver and kidney of laying hens. J. Anim. Physiol. Anim. Nutr. 2018, 102, 1199-1209. [CrossRef] [PubMed]

43. Qiu, Y.L.; Cheng, X.N.; Bai, F.; Fang, L.Y.; Hu, H.Z.; Sun, D.Q. Aucubin protects against lipopolysaccharide-induced acute pulmonary injury through regulating Nrf2 and AMPK pathways. Biomed. Pharmacother. Biomed. Pharmacother. 2018, 106, 192. [CrossRef]

44. Becker, T.M.; Juvik, J.A. The role of glucosinolate hydrolysis products from Brassica vegetable consumption in inducing antioxidant activity and reducing cancer incidence. Diseases 2016, 4, 22. [CrossRef] [PubMed]

45. Loboda, A.; Damulewicz, M.; Pyza, E.; Jozkowicz, A.; Dulak, J. Role of Nrf2/HO-1 system in development, oxidative stress response and diseases: An evolutionarily conserved mechanism. Cell. Mol. Life Sci. Cmls 2016, 73, 3221-3247. [CrossRef] [PubMed]

46. Dermit, M.; Dodel, M.; Mardakheh, F.K. Methods for monitoring and measurement of protein translation in time and space. Mol. Biosyst. 2017, 13, 2477-2488. [CrossRef] [PubMed]

Sample Availability: Not available. 